12. Проект колективного договору з Профспілка залізничників і транспортних ПАТ «Українська залізниця» будівельників України. - Режим доступу : [Електронний ресурс]: інформація / http://zalp.org.ua/

Стаття надійшла: 11.10.16p.

УДК 331.2

\title{
УДОСКОНАЛЕННЯ СИСТЕМИ ОПЛАТИ ПРАЦІ НА ЗАЛІЗНИЧНОМУ ТРАНСПОРТІ УКРАЇНИ
}

\author{
Маслова В.О., к.е.н., доцент, \\ Лісна О.О., магістр (УкрДУЗТ)
}

У статті обгрунтовано удосконалення системи оплати пращуі на підприємствах та у виробничих підрозділах залізничного транспорту як найбільш дієвого мотиваційного методу впливу на підвищення результатів пращі в сучасних умовах господарювання. Визначено особливості організації оплати прачі на залізничному транспорті. Наголошено на необхідності підвищення мотиваџіï пращзі працівників, які впливають на якісні та кількісні показники роботи залізничного транспорту, у тому числі за рахунок впровадження елементів грейдингу.

Ключові слова: мотивація праці, система оплати праці, грейдинг, залізничний транспорт.

\section{УСОВЕРШЕНСТВОВАНИЕ СИСТЕМЫ ОПЛАТЫ ТРУДА НА ЖЕЛЕЗНОДОРОЖНОМ ТРАНСПОРТЕ УКРАИНЫ}

\author{
Маслова В.А., к.э.н., доцент, \\ Лесная О.А., магистр (УкрГУЖТ)
}

В статье обосновано усовершенствование системы оплаты труда на предприятиях и в производственных подразделениях железнодорожного транспорта как наиболее действенного мотивационного метода влияния на повышение результатов труда в современных условиях хозяйствования. Определены особенности организации оплаты труда на железнодорожном транспорте. Отмечена необходимость повышения мотиваџии труда работников, влияющих на качественные и количественные показатели работы железнодорожного транспорта, в том числе за счет внедрения элементов грейдинга.

Ключевые слова: мотивация труда, система оплаты труда, грейдинг, жселезнодорожный транспорт.

(C) Маслова B.O.,

Лісна О.O.

Вісник економіки транспорту і промисловості № 55, 2016 


\title{
IMPROVEMENT OF SYSTEM OF COMPENSATION ON RAILWAY TRANSPORT OF UKRAINE
}

\author{
Maslova V.O., PhD Econ., associate professor \\ Lisna O.O., master (UkrSURT)
}

In article enhancement of a wages system at the entities and in production divisions of a rail transport as most efficient motivational method of influence on increase in results of work in modern conditions of managing is proved. Features and stages of the organization of compensation on railway transport are defined. Need of increase in motivation of work of the workers influencing quality and quantitative indices of work of railway are noted. Advantage of material motivation of work in comparison with non-material proceeding from an economic situation in the country and falling of a level of living of the population is proved. Advantages and shortcomings of introduction on railway transport of system of compensation on the basis of grades are specified (greyding). As an alternative to the last, it is offered uses of the principles of enhancement of a wages system at the entities of a rail transport which will allow to increase efficiency of use of the salary fund in compliance with results of activities, and also to provide motivation of the certain worker to increase in effectiveness of work.

Keywords: motivation of work, system of compensation, greyding, railway transport.

Постановка проблеми. Залізничний транспорт України - одна із найбільш соціально-орієнтованих галузей в державі, колектив якої об'єднує понад 300 тис. залізничників : колійників, енергетиків, зв'язківців, машиністів, провідників вагонів, диспетчерів, чергових по станціях та інших професій. Успішне виконання українською залізницею поставлених перед нею завдань, що полягають у задоволенні потреб у безпечних та якісних залізничних перевезеннях, забезпеченні ефективного функціонування та розвитку залізничного транспорту, створенні умов для підвищення конкурентоспроможності тощо, та досягнення запланованих результатів залежить від ефективності праці численного колективу залізничників. Як результат, постає питання про удосконалення мотивації підвищення результатів праці залізничників.

Аналіз останніх досліджень $\boldsymbol{i}$ публікацій. Серед вітчизняних дослідників, які досить широко в своїх роботах висвітлюють особливості мотивації праці, нормування та оплати праці на залізничному транспорті, слід виділити: Євсєєву О.О. [1], Єрофєєнко
Л.В. [2], Компанієць В.В. [3, 4], Куделя В.I. [5], Ляшенка I.О. [6], Польову В.В. [4], Сначова М.П. [6], Токмакову I.В. [7] та інших, а також провідних фахівців залізничної галузі таких як: Андрощук С. [8], Ейтутіс Г.Д. [9], Скрипка А. [10]. В своїх дослідженнях автори різносторонньо розглядають поставленні питання, як із соціально-моральних засад, так із економічних перспектив.

Виділення невирішених частин загальної проблеми. На нашу думку, для досягнення максимальної результативності в роботі працівника, у тому числі й на залізничному транспорті, необхідно на перше місце поставити задоволення його потреб як індивідуальної та неповторної особистості, зі своїм характером, сприйняттям та реагуванням на ті процеси, що відбуваються на підприємстві, у тому числі й у мотивації.

Метою cmammi є обгрунтування удосконалення системи оплати праці на підприємствах та у виробничих підрозділах залізничного транспорту як найбільш дієвого мотиваційного методу впливу на підвищення результатів праці.

Виклад основного матеріалу. 
Управління людськими ресурсами в умовах сучасної економіки в організаціях стає одним із провідних напрямків їх розвитку. При цьому в нових умовах зберігаються стандартні завдання адміністрування персоналу, але стиль управління людськими ресурсами тепер повинен відповідати стратегічній концепції управління самої організації. Людські ресурси стають одним із ключових факторів успіху, які безпосередньо впливають на досягнення стратегічних цілей організації. У свою чергу, для вирішення питань пов'язаних 3 досягненням стратегічних цілей компанії, 3 утримання та залучення нових співробітників (активних, ініціативних, цілеспрямованих фахівців), підвищення результативності персоналу необхідна ефективна система мотивації праці. Вона має відповідати як вимогам зовнішнього i внутрішнього середовища, так i задоволенню потреб працівників. Тому однією 3 головних функцій трудового права стає закріплення, забезпечення та захист основних прав і свобод людини у сфері праці та оплати за неї [9].

Як відомо, існують два види мотивації: матеріальна та нематеріальна (психологічна, соціальна). Матеріальна мотивація передбачає отримання певних матеріальних благ, які можуть бути виражені в грошовому вираженні, матеріальних об'єктах або послуги. Цей вид мотивації персоналу як раз i застосовується на рівні мотивації окремого співробітника. Нематеріальна мотивація спрямована на отримання співробітниками емоційних вигод, таких як підвищення самооцінки, психологічний комфорт, гордість за працю та ін. Найбільш часто цей вид застосовують на рівні мотивації всього колективу організації.

Зміна економічної ситуації в Україні, стрімкий розвиток недержавного сектора економіки, різноманітних форм власності та видів господарювання потребують удосконалення трудового законодавства, зокрема в оплаті праці [1].
Встановлена на підприємстві система оплати праці, яка враховує складність праці, дає можливість зрозуміти, що в діяльності працівника приносить результат, створює перспективи кар'єрного росту на службі та формує відчуття справедливості на сьогоднішній день найбільш мотивує працівників до продуктивної праці, оскільки являє собою винагороду або заробіток, що обчислюється в грошах та виплачується працівнику за якісне виконання ним певного обсягу роботи.

Нажаль, на підприємствах залізничного транспорту в останні роки склалася така тенденція, що в умовах постійного зниження вантажообігу та пасажирообороту через падіння обсягів виробництва майже за всіма галузями національної економіка та погіршення рівня життя населення, чи не єдиним заходом зниження витрат діяльності та підвищення iї ефективності стало скорочення фонду оплати праці через введення режиму неповного робочого дня та робочого тижня, відпусток за свій рахунок тощо. Безсумнівно, подібна практика не тільки знижує рівень задоволення потреб працівників, але й не сприяє зростанню мотивації останніх до праці належної якості у встановлених обсягах. Саме тому, удосконалення системи оплати праці на українських залізницях є найбільш рушійним методом впливу на результативність роботи їх працівників в умовах сьогодення.

Організація оплати праці на залізничному транспорті має свої особливості та складається 3 наступних етапів:

1) нормування праці;

2) розробка форм і систем оплати праці;

3) тарифне нормування заробітної плати.

До нормування праці відноситься розроблення та застосування прогресивних, технічно обгрунтованих норм витрат праці, основним завданням якого $\epsilon$ визначення необхідних витрат 
живої праці на виконання певної роботи. Нормування праці тісно пов'язане 3 iï оплатою. Норми переглядають у зв'язку із змінами в трудових та виробничих процесах, які підвищують продуктивність праці [2].

На залізничному транспорті застосовується погодинно-преміальна та відрядно-преміальна форми оплати. Оплата праці основних груп працівників залізничного транспорту здійснюється за різними формами (наприклад, оплата праці локомотивних бригад всіх видів пасажирського руху здійснюється за погодинно-преміальною системою, у вантажному русі - за відряднопреміальною системою за локомотивокілометри). Встановлення форми оплати праці на залізничному транспорті залежить від об'єктивних показників таких як умови праці, технічний прогрес, характер та обсяг роботи.

Для диференціального регулювання оплати праці застосовується тарифна система, яка являється системою спеціальних нормативів, за допомогою яких встановлюється заробітна плата різних категорій працівників 3 урахуванням складності, інтенсивності роботи та умов праці. До iї складу входять: тарифна сітка, тарифні ставки, схеми посадових окладів та тарифнокваліфікаційні

(довідники) [6].

Система

преміювання, що застосовується на підприємствах залізничного транспорту, в принципі, враховує мотивацію тих працівників, які впливають на якісні та кількісні показники роботи залізничного транспорту. Так, наприклад, для локомотивних бригад, які працюють у вантажному виді руху, за виконання технічної швидкості за результатами роботи за місяць чи квартал, яка безпосередньо впливає на якісні показники роботи залізниці в цілому, введена додаткова премія. Для більш якісного виконання робіт 3 ремонту тягового рухомого складу та спеціальної техніки в розрізі як поточних, так i капітальних видів ремонту, розроблена та впроваджується система додаткового матеріального заохочення за якість та надійність відремонтованих вузлів та агрегатів.

Однак на даний час щомісячна виплата премії, яка за деякими професіями може досягати $50 \%$ i більше середньомісячної заробітної плати, сприймається залізничниками як обов'язкова складова частина останньої, тому зменшення премії чи позбавлення іiі повністю, наприклад, за порушення внутрішнього трудового розпорядку чи допущення недоліків у роботі, сприймається - як покарання. Хоча невиплата премії не відноситься до видів покарань. Крім того, особливістю діяльності залізничного транспорту $\epsilon$ взаємозалежність результатів роботи одних підрозділів від результатів роботи інших підрозділів. Так виконання плану 3 тієї ж технічної швидкості машиністами залежить від результативності праці в дистанціях шляху, енергопостачання, зв'язку. За таких умов часто відсутня прозорість у нарахуванні премій, а отже значно послаблюється мотиваційний ефект самої системи преміювання.

Для створення сприятливих умов, спрямованих на задоволення потреб як залізничного транспорту, так i працівників, необхідно враховувати досвід світової практики, яка все частіше використовує грейдингову систему оплати праці. Грейдинг або грейдерування (від англійського grading - класифікація, сортування, упорядкування) - це процес створення вертикальної структури посадових рівнів і розрядів, універсальної для всього персоналу організації, де всі посади збудовані в залежності від їх значимості та орієнтовані на стратегію і бізнес-цілі підприємства. На залізничному транспорті, на нашу думку, найбільш ефективним буде грейдерування посад, ніж грейдерування працівників, враховуючи багаточисленний контингент галузі, складність праці та необхідність забезпечення безпеки руху пасажирів та 
вантажів.

Серед основних факторів, які допоможуть у вирішенні поставлених питань та у досягненні цілей, при застосуванні на залізничному транспорті системи грейдингу, слід відзначити наступні [4]: 1) сприяння управлінню фондом оплати праці та створення більш гнучкої системи нарахування заробітної плати; 2) підвищення ефективності оплати праці; 3) упорядкування дисбалансу нарахування зарплати (нарахування стають прозорими, прибуток працівників, які досягли результатів, підвищується за рахунок лінивих та непотрібних працівників); 4) сприяння виявленню рівнів і підрозділів 3 невідповідними нарахуваннями зарплати; 5) допомагає виключити роботи, що не впливають на ефективність діяльності підприємств.

Втім, варто зазначити, що докорінна реорганізація існуючої та впровадження оплати праці залізничників полягає у тому, щоб постійна частина заробітної плати перевищувала змінну. Тільки за таких умов вона буде змушувати працівників виконувати встановлений план для отримання більшої частини свого заробітку. Змінна ж частина буде встановлювати остаточну справедливість за рахунок тільки тих премій, які чітко дають зрозуміти, за що отримав їх працівник (за свій внесок в результати роботи підрозділу або підприємства в цілому). При цьому, чим менше всяких доплат в змінній частині, тим краще працівник розуміє, що він повинен зробити для того, щоб отримати змінну частину зарплати.

Висновок. 3 вищенаведеного можна зробити висновок, що застосування на підприємствах залізничного транспорту наведених вище принципів удосконалення системи оплати праці, що відповідають перевагам грейдингової системи, дозволить не тільки підвищити ефективність використання фонду оплати праці відповідно до результатів діяльності, але й кожному працівнику відчути себе індивідуальною складовою грейдингової системи оплати праці на залізничному транспорті - це досить кропіткий, довготривалий та витратний процес, у той час як підвищувати ефективність праці, а також зберегти висококваліфіковані кадри серед залізничників, забезпечивши їм, перш за все, гідну заробітну плату, необхідно вже сьогодні.

Основний принцип удосконалення системи оплати праці на підприємствах залізничного транспорту сьогодні повинен полягати у тому, щоб формування заробітної плати відбувалося не зверху до низу, а знизу нагору, тобто від індивідуальної зарплати до загального розміру фонду, та враховувати в системі оплати особистий вклад працівника в загальну справу, заохочувати ініціативу та інноваційну спрямованість працівника [7]. Інший, не менш важливий принцип, удосконалення системи багатофункціонального механізму, який працює для задоволення як своїх, так i суспільних інтересів, отримати гідну своєї праці заробітну плату та, врешті-решт, підвищити мотивацію до зростання продуктивності та якості праці.

\section{СПИСОК ЛІТЕРАТУРИ}

1 Євсєєва О.О. Удосконалення системи стимулювання ефективної роботи колективів підприємств залізничного транспорту: автореф. дис. на здобуття наук. ступеня канд. екон. наук: спец. 08.06.01 «Економіка, організація i управління підприємствами» О.О.Свсєєва. - Харків, 2004. - 25 с.

2 Ерофєєнко Л.В. Специфіка системи оплати праці на залізничному транспорті / Л.В.Єрофєєнко // Право і безпека. - 2009. - № 5. - С. 44-47.

3 Компанієць В.В. Управління розвитком соціально-економічних систем у духовно-моральному та соціокультурному вимірі. Частина II. Якість управління соціальноекономічними системами: духовноморальні та культурні пріоритети (на 
прикладі залізничного транспорту): монографія / В.В.Компанієць. - Харків: УкрДАЗТ. - 2012. - 296 с.

4 Компанієць В.В. Впровадження компетентного підходу у систему підготовки, оцінки та відбору кадрів залізничного транспорту

В.В. Компанієць, В.В. Польова // Вісник економіки транспорту і промисловості: Зб. наук. праць. - Харків: УкрДАЗТ. - 2013. № 44. - С. 46-53.

5 Куделя B.I. Теоретичний підхід до проблем мотивації персоналу на залізничному транспорті / В.І. Куделя, В.Г. Яковенко // Вісник економіки транспорту i промисловості: 3б. наук. праць. - Харків: УкрДАЗТ. - 2013. - №44 C. 273-275.

6 Ляшенко I.O. Мотивація праці на залізничному транспорті в умовах його реформування / I.O. Ляшенко, М.П. Сначов // Зб. наук. праць Дніпропетровського національного університету залізничного транспорту імені академіка В.Лазаряна. Дніпропетровськ: ДНУЗТ. - 2011. - Вип.
2: Проблеми економіки транспорту. - С. 48-55.

7 Токмакова I.В. Мотивація трудової поведінки працівників підприємств залізничного транспорту в умовах реформування / І.В. Токмакова // Вісник економіки транспорту i промисловості: Зб. наук. праць. - Харків: УкрДАЗТ. - 2013. - № 44. - С. 286-289.

8 Андрощук С. Реформа мотивації [Електронний ресурс] - Режим доступу: http://www.magistral-uz.com.ua/artikles /motivacija -personala.html.

9 Ейтутіс Г.Д. Мотивація як фактор впливу на ефективність виробничих структурних підрозділів залізничного транспорту на прикладі дистанції колії / Г.Д. Ейтутіс, О.А. Мельникова // Вісник економіки транспорту і промисловості: Зб. наук. праць. - Харків: УкрДАЗТ. - 2013. № 42. - C. 412-416.

10 Скрипка А. Мотивация персонала [Електронний ресурс] - Режим доступу: http://www.magistral-

uz.com.ua/artikles/motivacija-personala.html.

Стаття надійшла: 04.10.16p.

\title{
УДК 371.000.141
}

\section{НЕОБХОДИМОСТЬ РАЗВИТИЯ ФИЛОСОФИИ ОБРАЗОВАНИЯ В СОВРЕМЕННЫХ УСЛОВИЯХ}

\author{
Сухорукова Т.Г., к.э.н., доцент, \\ Боровик Ю.Т., к.э.н., доцент (УкрГУЖТ)
}

В статье исследована история развития понятия «философия образования», обоснована необходимость формирования новой парадигмы образования в современных условиях, раскрыты цель и задачи философии образования с учетом современных реалий. Основными направлениями философии образования являются духовность, творчество, развитие и культура. В статье отмечается высокая роль самообразования, как основного фактора повышения качества знаний трудящихся. Несмотря на изначально философский характер, рассматриваемая наука имеет тесную связь с практикой, поскольку оперирует такими понятиями, как образованньии человек, идеал образованности, образовательные технологии.

(C) Сухорукова Т.Г., Боровик Ю.Т. 